\title{
NON-CONFORMITIES ANALYSIS IN THE INDUSTRIAL MANUFACTURING PROCESSES
}

\author{
Elena-Mădălina MILITARU (BRATU), Roxana Alexandra GHEȚA, \\ Andrei-Valentin BRATU, Gabriel Marius DUMITRU, \\ Gabriel IACOBESCU \\ POLITEHNICA University of Bucharest \\ e-mail: militaruemadalina@yahoo.com,roxana_gheta@yahoo.com,br.andrei@yahoo.com, \\ gmdumitru@yahoo.com, gabiiacobescu@yahoo.com
}

\begin{abstract}
The current article presents the identification, treatment method and encoding of causes that generate defects and types of non-conformities encountered during the manufacturing process in industry.

The analysis is performed periodically: monthly, quarterly, yearly, compared to the results of previous similar periods. This process is the basis for establishing the necessary corrective/ preventive measures.

The purpose of this study is to show how to achieve data centralization needed to prevent non-quality.
\end{abstract}

KEYWORDS: industry, turbine components, non-conformity, Quality Plan (QP), Corrective Action Report (RAC)

\section{Introduction}

This article aims to analyse how to deal with non-conformities occurring in the manufacturing of turbine components, generators and compressors used in energy industry.

Each company, through the entities involved, plans and develops the processes necessary to deliver the products contracted in accordance with the design documentation and the contractual requirements [1]. The product planning activity starts with the analysis of the customer's requirements through calls for proposals and contract proposals. Output data of the customer requirements analysis determines the quality objectives, product requirements and processes, specific documents and resources expressed through the Quality Plan-QP and the technological documentation [2]. Providing verification plans at the reception desk based on risk strategies known and accepted by all the entities involved in the production process to ensure delivery to the beneficiary of the contractually agreed quality $[3,4,12]$.

\section{Method}

The Quality Plan-QP is used to keep checks on the activities carried out and to provide records on their performance. Its requirements are developed from the early stages of the implementation activities, identifying the sequence of the inspections and tests steps required to demonstrate the fulfilment of the requirements, the means by which they are verified, and the acceptance criteria [5]. It is thus possible to demonstrate permanently the control of the checks made and of the issued registrations.

The records are necessary to provide evidence that the manufacturing processes and the resulting product meet the requirements, in accordance with the technological documentation, constructional design documentation and customer requirements.

\subsection{Opening the non-conformity report}

The organization must ensure that the nonconform product is identified and kept under control to prevent unauthorized use or delivery.

The analysis of the treatment of nonconformities will be made based on the methodology for identifying, registering, completing, disseminating, circulating, tracking and solving NonConformity Reports - NR issued as a result of nonconformities to products and services [4].

Control personnel who identify the nonconformity and initiates NR need to know the 
domain and range of products under manufacturing as well as the type of possible non-conformities.

Execution staff, upon finding a non-conformity, immediately stops the execution of the landmark (if possible) and announces the job manager and the Quality Control Department staff to analyse the noncompliance and prepare the NR [4].

These NR are forwarded to the Non-Compliance Analysis Commission, whose component and competence is established based on an internal decision, according to the requirements of the Integrated Management System. Analysing and solving RNs is an ample process involving management personnel; due both to the costs of eliminating non-compliance and to the need to obtain certain approvals/exemptions.

If the nonconformity is found to be due to a failure of the machines or equipment used to obtain the product, then the activity will be stopped immediately, requiring reconditioning and repair $[6$, 7].

In order to identify and track the non-conform product, it is necessary to record its data from the
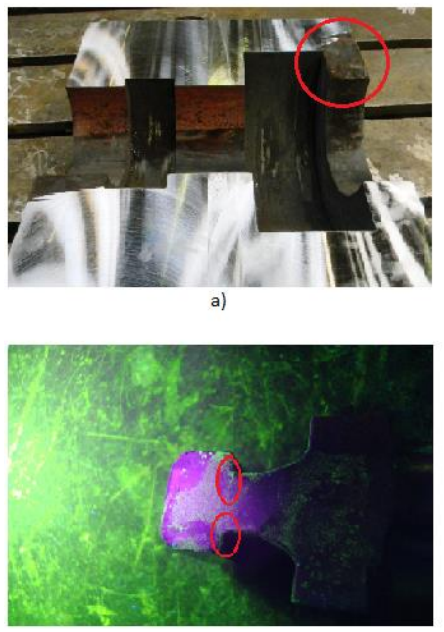

c) technological documentation, the existing marking on the part and the codes from: the list of the codes of non-conformities causes; a list of defects codes; a list of job codes; a list of existing machine codes within the company.

Determining the cause and defect code that generated the non-conformity is performed by the inspector within the workshop where the nonconformity was found.

\subsubsection{Documents of non-conformity report}

For the dimensional deviations are made measurements sheets, drawings, passports, which are attached to the NR and are mentioned therein $[9,10]$.

For deviations identified by visual inspection (see Fig. 1), chemical analysis, mechanical tests, hydraulic or pneumatic probes, the records issued (test bulletins, photo if defects are visible - see Fig. 2) are attached to the NR and are also mentioned therein.
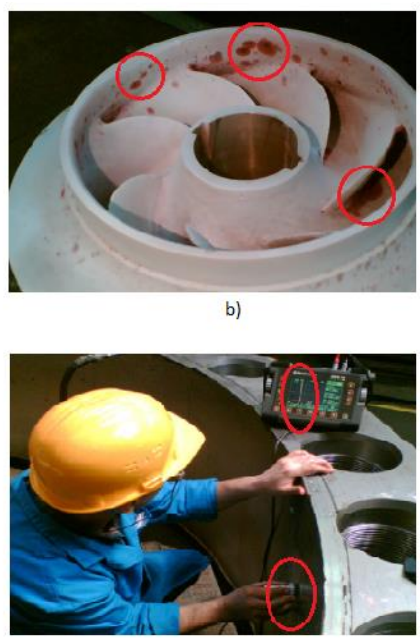

Fig. 1. Non-conformities identified following inspection: a) visual; b) penetrating fluids; c) magnetic powders; d) ultrasound

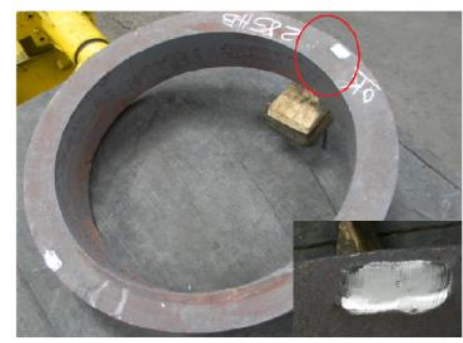

a)

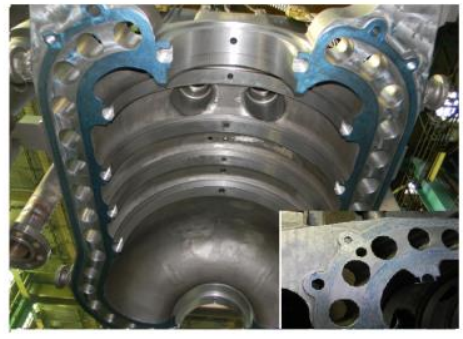

b)

Fig. 2. Non-conformities identified after: a) Brinell hardness testing; b) Sealing testing (pneumatic test) 
After registering the non-conformity identification data and its description in the NR, the Quality Control Department determines whether the non-conformity found is repeatable to initiate corrective actions to prevent recurrence of similar non-conformities [13, 14].

Framing of non-conformity is done by the product engineer, as follows [17]:

- Scrap;

- Repair/ reprocessing [5] - can be returned to the project requirements (description of the solution);

- Acceptance without modification - no longer meet project requirements;

- Conditional acceptance - description of the required conditioning.

Filling in chapters and NR circulation is performed according to the framing of the nonconformity, as follows:

a) Non-conform product-scrap

For rebutted products the financial records, the costs generated by non-conformity will be operated and the production department will work in order to transfer the product to the scrap storehouse (if the product is not over-sized).

b) Non-conform product that can be brought to the project requirements by repair / reprocessing

Following the analysis of the NR by the Commission, the product engineer will launch a number of additional operations to resolve the nonconform product, operations that are always completed with a control operation, as a result of which the product may continue to flow or be discarded, depending on the result of this control.

c) Non-conform product that is being promoted with established deviations (conditional acceptance or acceptance without modification)

There are situations when the non-conformity cannot be removed, especially in the case of oversized products, and the cost of repatriation is extremely high. In these situations, a Request for Derogation is drawn up following a meticulous analysis of the project, a request which will be approved by the Non-Compliance Analysis Commission and which will eventually reach the client for acceptance.

\subsection{Opening the non-conformity report}

Following the analysis of the annexes to NR and the company's strategy for reducing and preventing the occurrence of non-conformities, the Coordinator of the Nonconformities Analysis Commission writes the necessary comments for the improvement of the process [14]. His opinion at the closure of the NR attests the fact that all the departments involved in the nonconformity analysis and resolution have solved their specific tasks $[15,16]$.

After the closure of the NR, it is analysed by the Nonconformities Analysis Commission. The NR can also be analysed during the resolution of the nonconformity by the various compartments involved in the solution. The analysis also includes the number of non-destructive examination controls performed, the Corrective Action Report, RAC, issued, the number of Requests for Exemption, the number of products approved for manufacturing, the data necessary to establish the specific trends of the various processes involved, the general data needed for the analysis, the number of open NR monthly etc.

\section{Case study}

Table 1 shows a defect-generating pattern coding model.

Table 1. Encoding defective causes

\begin{tabular}{|c|c|l|}
\hline Code & Defective cause & \multicolumn{1}{|c|}{ Cause description } \\
\hline 0 & 1 & \multicolumn{1}{|c|}{2} \\
\hline 01 & Execution planning & $\begin{array}{l}\text { The process of developing the manufacturing plan is } \\
\text { inappropriate, resulting in an error in the technological sheet, the } \\
\text { technological scheme, the worksheet or the working instructions; } \\
\text { lack of execution documentation. }\end{array}$ \\
\hline 02 & Communication & $\begin{array}{l}\text { Inappropriate presentation of information, whether spoken or } \\
\text { written. }\end{array}$ \\
\hline 03 & $\begin{array}{c}\text { Inappropriate technical } \\
\text { documentation }\end{array}$ & $\begin{array}{l}\text { Inappropriate design style, without complying with standards or } \\
\text { technical standards; non-updated documentation; inadequate } \\
\text { documentation of the technological flow and product } \\
\text { requirements. }\end{array}$ \\
\hline 04 & $\begin{array}{c}\text { Parameters of the } \\
\text { technological operation }\end{array}$ & $\begin{array}{l}\text { Working parameters (speed, speed rate, feed, cutting depth, etc.) } \\
\text { are not defined, monitored or measured; non-observance of the }\end{array}$ \\
\hline
\end{tabular}




\begin{tabular}{|c|c|c|}
\hline & & $\begin{array}{l}\text { working parameters of the established technical requirements. For } \\
\text { special processes: non-observance of the indicated parameters } \\
\text { (voltage, current, temperature, time, machinery, monitoring, etc.) } \\
\text { and/or the execution phases and inter-operational control. }\end{array}$ \\
\hline 05 & The technological process & $\begin{array}{l}\text { Technological capacity (capability) is not able to generate the } \\
\text { product according to drawing or documentation; failing to meet } \\
\text { the specified product requirements; non-correlation of the } \\
\text { technological sheet with the Quality Plan; non-compliance with } \\
\text { contract requirements. }\end{array}$ \\
\hline 06 & Cutting tools & $\begin{array}{l}\text { An error caused by the cutting tool that breaks, cracks, presents } \\
\text { deviations from the machining axes, is incorrectly sharpened, is } \\
\text { used over the length of use between two sharpening, etc.; lack of } \\
\text { cutting tools indicated in the execution documentation. }\end{array}$ \\
\hline 07 & Machine tool & $\begin{array}{l}\text { Working parameters that do not ensure the conditions imposed on } \\
\text { the product; presents unforeseen failures during execution, } \\
\text { numerically controlled/inadequately controlled or inadequate } \\
\text { product to be executed. }\end{array}$ \\
\hline 08 & Fixtures or clamping devices & Improperly chosen/unprotected or damaged. \\
\hline 09 & $\begin{array}{l}\text { Measuring systems and } \\
\text { devices }\end{array}$ & $\begin{array}{l}\text { Erroneous measurements due to lack of maintenance, } \\
\text { inappropriate exploitation, or erroneous calibration/ verification. }\end{array}$ \\
\hline 10 & Electrical parameters & $\begin{array}{l}\text { The product's electrical parameters are inadequate to the required } \\
\text { requirements. }\end{array}$ \\
\hline 11 & Management decisions & $\begin{array}{l}\text { Errors due to omitted operations, inappropriate } \\
\text { programming/ordering/choice of technology or due to a decision } \\
\text { that deviates from the instructions of the execution and/or control } \\
\text { documentation or other specified requirements. }\end{array}$ \\
\hline 12 & Major force & $\begin{array}{l}\text { Errors caused by fire, voltage drop or other unforeseen factors. } \\
\text { Human error is excluded. }\end{array}$ \\
\hline 13 & Climatic factors & $\begin{array}{l}\text { Errors caused by execution at low/high temperatures, humidity, } \\
\text { inadequate or excessive lighting, noise etc. }\end{array}$ \\
\hline 14 & $\begin{array}{l}\text { Storage (includes stock } \\
\text { items) }\end{array}$ & $\begin{array}{l}\text { Inappropriate storage or preservation (rust, surface defects, } \\
\text { cracks, deformations, non-destructive controls, etc.); the } \\
\text { disappearance of identification marks due to improper storage } \\
\text { conditions. Failure to observe the shelf life of the applied } \\
\text { materials, failure to perform periodic inspections of the protection } \\
\text { before and during storage. }\end{array}$ \\
\hline 15 & $\begin{array}{l}\text { Personnel training/ } \\
\text { qualification }\end{array}$ & $\begin{array}{l}\text { Incomplete or inadequately qualified personnel for the execution } \\
\text { of the planned operations; not properly trained for current work. }\end{array}$ \\
\hline 16 & Human error & $\begin{array}{l}\text { Execution documentation, instructions, or technical procedures } \\
\text { for the related processes have not been followed, or any } \\
\text { deviations of the staff from the specified requirements have been } \\
\text { worked out, resulting in non-conformities. }\end{array}$ \\
\hline 17 & $\begin{array}{l}\text { Handling / Packing / } \\
\text { Preservation }\end{array}$ & $\begin{array}{l}\text { Error caused by inappropriate handling, packaging and/ or } \\
\text { conservation (on the products to be delivered). }\end{array}$ \\
\hline 18 & Documentation control & $\begin{array}{l}\text { Inappropriate distribution, circulation and retention of } \\
\text { technologies, instructions, procedures, drawings and other } \\
\text { documents, or the lack of quality documents required for executed } \\
\text { products. }\end{array}$ \\
\hline 19 & Suppliers control & $\begin{array}{l}\text { Failure to observe the procedure of choice, approval, qualification } \\
\text { and supervision of suppliers = hidden vices of the material; } \\
\text { defects resulting from the technological process of material } \\
\text { preparation and treatment (casting, forging, rolling, moulding, } \\
\text { etc.). It also includes defects on delivered products that require } \\
\text { further reshuffle/ reprocessing within the company. }\end{array}$ \\
\hline 20 & Material replacement & $\begin{array}{l}\text { The material required by the documentation is not available or } \\
\text { does not meet the required conditions. }\end{array}$ \\
\hline
\end{tabular}




\begin{tabular}{|c|c|c|}
\hline 22 & $\begin{array}{l}\text { Problems caused by the } \\
\text { client }\end{array}$ & $\begin{array}{l}\text { Existing defects in parts, subassemblies, or materials that have } \\
\text { been made available by the customer and not included in the } \\
\text { Minutes of Finding or accompanying quality records (including } \\
\text { their hidden vices) [18]. }\end{array}$ \\
\hline 23 & Special processes & $\begin{array}{l}\text { Welding, thermal treatments, thermostabilizing, creep, dyeing/ } \\
\text { coatings, etc., which do not meet the established requirements or } \\
\text { do not lead to the requirements imposed on the product. }\end{array}$ \\
\hline 24 & Product not received & $\begin{array}{l}\text { Product entered in the execution process without qualitative } \\
\text { reception }\end{array}$ \\
\hline 25 & Resource assurance & $\begin{array}{l}\text { Missing Tools and Verification Devices (TVD) indicated in the } \\
\text { documentation; lack of measurement and monitoring devices; } \\
\text { lack of consumables (oil, emulsions etc.), lack of equipment } \\
\text { needed for technological support; inappropriate human resources } \\
\text { [19]. }\end{array}$ \\
\hline 26 & Customer benefit & $\begin{array}{l}\text { Includes non-conformities to products executed by the company, } \\
\text { but due to the collaboration between the customer and the client, } \\
\text { by performing works directly at the company's headquarters. }\end{array}$ \\
\hline
\end{tabular}

Table 2. Encoding defective causes

\begin{tabular}{|c|c|c|}
\hline Code & Class defects & Defect \\
\hline 0 & 1 & 2 \\
\hline A. & $\begin{array}{c}\text { Constructive design } \\
\text { defects }\end{array}$ & $\begin{array}{l}\text { 1. Incorrect or incomplete specification } \\
\text { 2. Incorrect or incomplete specified material } \\
\text { 3. Requiring inappropriate specific technology documentation } \\
\text { 4. Component of the product improperly specified } \\
\text { 5. Inappropriately specified procedures and applications } \\
\text { 6. Inappropriate drawing detail } \\
\text { 7. Incorrect dimensional specification } \\
\text { 8. Non-specification of deviations in form and position in drawings } \\
\text { 9. Highlights identified inappropriately in the project } \\
\text { 10. Conflict of specifications in the drawing } \\
\text { 11. Inadequate project documentation requirements } \\
\text { 12. Incorrect adaptation or non-adaptation of external documentation }\end{array}$ \\
\hline$B$. & $\begin{array}{l}\text { Technological } \\
\text { design defects }\end{array}$ & $\begin{array}{l}\text { 1. Incorrect or incomplete specified material } \\
\text { 2. Inappropriately specified size } \\
\text { 3. Inappropriately specified procedures and applications } \\
\text { 4. Inappropriate sketch detail } \\
\text { 5. Non-specification in sketches of deviations of form and position } \\
\text { 6. Inappropriate choice of machine tools } \\
\text { 7. Mistaken choice of the base and catch of the piece in the device } \\
\text { 8. The wrong choice of the base and the catch of the piece on the tool } \\
\text { machine } \\
\text { 9. Inappropriate indication of cutting tools } \\
\text { 10. Inappropriate indication of the means of measurement } \\
\text { 11. Misrepresentation or misrepresentation of cutting regimes } \\
\text { 12. Non-specification in all technological documentation } \\
\text { 13. the requirements in the constructive documentation } \\
\text { 14. Specifying documents in the technical documentation that are not } \\
\text { permanently accessible to the performer }\end{array}$ \\
\hline$C$. & Processing defects & $\begin{array}{l}\text { 1. Dimensional deviations } \\
\text { 2. Deviations of form } \\
\text { 3. Position deviations } \\
\text { 4. Deviations of balance } \\
\text { 5. Inappropriate rug }\end{array}$ \\
\hline
\end{tabular}




\begin{tabular}{|c|c|c|}
\hline & & $\begin{array}{l}\text { 6. Inappropriate hole } \\
\text { 7. Tool inlet on the processed surface } \\
\text { 8. Traces of scratches, cuts and/ or strokes on the surface processed } \\
\text { 9. Threaded holes with splines, broken spines, incomplete or overlapped } \\
\text { splines } \\
\text { 10. Absence or extra hole } \\
\text { 11. Holes/ holes in the grille offset } \\
\text { 12. Addition of insufficient processing } \\
\text { 13. Use of inappropriate devices } \\
\text { 14. Use of inappropriate tools } \\
\text { 15. Using an inappropriate machine } \\
\text { 16. Stepped surfaces } \\
\text { 17. Addition of insufficient material for the finishing operation } \\
\text { 18. Debit is wrong } \\
\text { 19. Inappropriate deburring }\end{array}$ \\
\hline$D$. & Assembly defects & $\begin{array}{l}\text { 1. Unassembled or omitted landmark } \\
\text { 2. Inappropriate fitting } \\
\text { 3. Installation made without accuracy } \\
\text { 4. Non-compliant mounting games } \\
\text { 5. Failure to comply with the procedural test conditions } \\
\text { 6. Grip, scratches, scratches due to inappropriate mounting } \\
\text { 7. Inserted an extra number of blades to the pallet operation }\end{array}$ \\
\hline$E$. & $\begin{array}{l}\text { Defects due to } \\
\text { special processes }\end{array}$ & $\begin{array}{l}\text { 1. Product deformation } \\
\text { 2. Inappropriate deposited/ existing layer thickness } \\
\text { 3.Physical-chemical characteristics of the deposited/ existing layer } \\
\text { inappropriate } \\
\text { 4. Superficial cracks } \\
\text { 5. Cracks in the depth of the material } \\
\text { 6. Lack of adhesion, composition delamination } \\
\text { 7. Welding inclusions } \\
\text { 8. Marginal burns, burning of the base material } \\
\text { 9. Inappropriate condition of rough surfaces (cast, forged) } \\
\text { 10. Use of overdue term materials } \\
\text { 11. Use of inappropriate materials } \\
\text { 12.Faults occurring in the manufacturing process (thermostabilization, } \\
\text { creep, etc.) other than those specified } \\
\text { 13.Form or position of the welding cord inappropriate to the } \\
\text { documentation } \\
\text { 14.Feathers, voids, bumps, crevices, marginal ditches, overlapping, burns } \\
\text { 15. Incorrect lake for electrical insulation } \\
\text { 16. Inappropriate varnish, non-uniform coating } \\
\text { 17. Prepare inappropriate surfaces: sand blasting outside the indicated } \\
\text { blasting degree; incomplete or inadequate degreasing; the presence of } \\
\text { oxides or rust on the sanded surfaces } \\
\text { 18. Inappropriate adhesion of film coating } \\
\text { 19. Inappropriate adhesion of metallic coatings } \\
\text { 20. Non-uniform thickness of protection or metallic coatings (under / over } \\
\text { imposed limits) } \\
\text { 21. Inappropriate anti-corrosion coatings on visual control } \\
\text { 22. Inappropriate packaging (use of materials other than those specified in } \\
\text { the applicable documentation) } \\
\text { 23. Conservation made with film-coated materials outside the supplier's } \\
\text { warranty period and without recertification } \\
\text { 24.Conservation made with materials other than those indicated in the } \\
\text { applicable documentation } \\
\text { 25. Use of wire, flux or electrodes with overdrive and without rectification }\end{array}$ \\
\hline
\end{tabular}




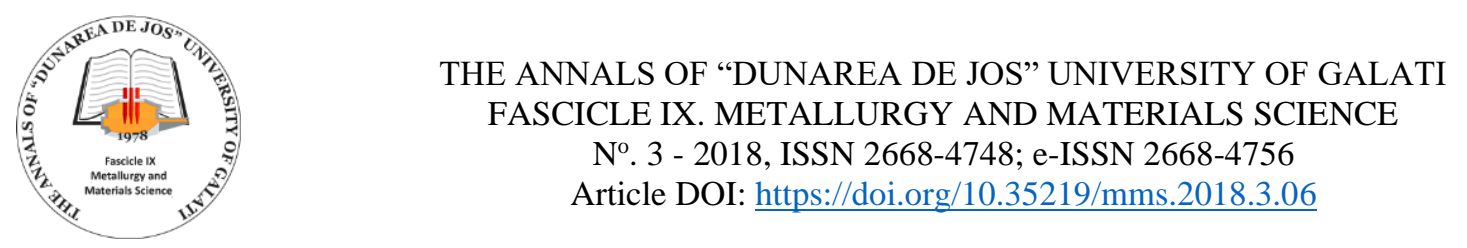

\begin{tabular}{|c|c|c|}
\hline$F$ & Material defects & $\begin{array}{l}\text { 1. Certificate of non-conforming material (incomplete) } \\
\text { 2. Deviations from specified chemical analysis } \\
\text { 3. Deviations of the specified mechanical characteristics } \\
\text { 4. Blows, inclusions, voids, cracks, overlaps, pores (highlighted with END } \\
\text { controls) [20,21] } \\
\text { 5. Specific heat treatment improperly applied }\end{array}$ \\
\hline$G$. & $\begin{array}{l}\text { Half-finished } \\
\text { product defects and } \\
\text { deviations of } \\
\text { landmarks from } \\
\text { customer/supplier }\end{array}$ & $\begin{array}{l}\text { 1. The surface with bumps, bumps, zigzags } \\
\text { 2. Dimensional deviations of rough surfaces } \\
\text { 3. Nonconforming concentricity } \\
\text { 4. No bosom, ribbing or inappropriate placement } \\
\text { 5. Dimensional deviations, incomplete material defects and incomplete } \\
\text { parts from customer/ supplier } \\
\text { 6. Macrostructure and inappropriate granulation } \\
\text { 7. Unsuitable protective or metallic coatings } \\
\text { 8. Deviations from the specified heat treatment } \\
\text { 9. Immature material (with a lifetime exceeding or at the technological } \\
\text { limit/ developed according to old standards - it is used for products made } \\
\text { available by the customer in the repairs) } \\
\text { 10. Defects of material revealed after reception (hidden vices). Includes } \\
\text { deviations from physico-chemical characteristics as well as defects } \\
\text { highlighted by subsequent non-destructive controls [20] }\end{array}$ \\
\hline$H$. & $\begin{array}{l}\text { Verification and } \\
\text { control defects }\end{array}$ & $\begin{array}{l}\text { 1. Use of a decalibrated measuring and checking tool } \\
\text { 2. Use of an inadequate measurement and verification tool } \\
\text { 3. Reading or interpreting error of measurement and control instrument } \\
\text { indication } \\
\text { 4. Erroneous entry of measured values in documents } \\
\text { 5. Lack of product quality records } \\
\text { 6. Lack of dimensional or visual control } \\
\text { 7. Lack of non-destructive control }\end{array}$ \\
\hline$I$. & $\begin{array}{c}\text { Storage and } \\
\text { environmental } \\
\text { defects }\end{array}$ & $\begin{array}{l}\text { 1. Impairment of surfaces due to inadequate storage according to the } \\
\text { requirements of the documentation } \\
\text { 2. Impairment of surfaces due to expiration of the term of protection of the } \\
\text { protection } \\
\text { 3. Inappropriate handling of flow, wire or electrodes }\end{array}$ \\
\hline
\end{tabular}

\section{Experimental values}

The experimental results to be presented were recorded over a month in an energy equipment producing organization.
The production is a small / unique series and the main activities within this organization are the manufacture, repair reconditioning of the energy equipment or cutting operations of the semi-finished products made available by the customer, most often being large. Table 3 shows experimental values.

Table 3. Experimental values

\begin{tabular}{|c|c|c|c|c|c|}
\hline $\begin{array}{c}\text { Ref. } \\
\text { no. }\end{array}$ & $\begin{array}{c}\text { No. NR/ } \\
\text { date }\end{array}$ & $\begin{array}{c}\text { Part designation } \\
\text { (object of the } \\
\text { contract) }\end{array}$ & $\begin{array}{c}\text { Cause } \\
\text { code }\end{array}$ & $\begin{array}{c}\text { Defect } \\
\text { code }\end{array}$ & \multicolumn{1}{|c|}{$\begin{array}{c}\text { Deviation description/ } \\
\text { Cause presentation }\end{array}$} \\
\hline 0 & 1 & 2 & 3 & 4 & 5 \\
\hline 1 & 14.01 .17 & $\begin{array}{c}\text { Kaplan pallet } \\
\text { chuck - semi- } \\
\text { finished product } \\
\text { (customer's semi- } \\
\text { finished product } \\
\text { processing) }\end{array}$ & 22 & $\mathrm{C} 4$ & $\begin{array}{l}\text { Following the centering of the palette on the } \\
\text { front track, it was found that the radial centering } \\
\text { surface shows the following deviations: 0 to } 0^{\circ} \\
\text { on the inlet edge; } 9 \mathrm{~mm} \text { at } 90^{\circ} ; 5.2 \mathrm{~mm} \text { at } 180^{\circ} \text { at } \\
\text { the exit edge and } 2.7 \mathrm{~mm} \text { at } 270^{\circ}[6] . \\
\text { The cause of the nonconformity is the erroneous } \\
\text { framing of the finished piece in the semi-finished }\end{array}$ \\
\hline
\end{tabular}




\begin{tabular}{|c|c|c|c|c|c|}
\hline & & & & & $\begin{array}{l}\text { product, made in the previous stage, which took } \\
\text { place within another organization. }\end{array}$ \\
\hline 2 & $\begin{array}{l}02 / \\
15.01 .17\end{array}$ & $\begin{array}{l}\text { Monobloc rotor } \\
\text { (customer's semi- } \\
\text { finished product } \\
\text { processing) }\end{array}$ & 16 & $\mathrm{C} 1$ & $\begin{array}{l}\text { When reframing the final piece in the blank, it } \\
\text { was found that the axial hole length of } 1345 \mathrm{~mm} \\
\text { would result in } 1190 \mathrm{~mm} \text {, the diameter of the } \\
\text { hole being the one desired, } \varnothing 76 \text {. } \\
\text { The cause of noncompliance is because the } \\
\text { existing additions to the rotor end have not been } \\
\text { considered. }\end{array}$ \\
\hline 3 & $\begin{array}{l}03 / \\
16.01 .17\end{array}$ & $\begin{array}{l}\text { Bowl (customer's } \\
\text { semi-finished } \\
\text { product } \\
\text { processing) }\end{array}$ & 16 & $\mathrm{C} 7$ & $\begin{array}{l}\text { The piece shows a tool inlet on the tilted flank of } \\
\text { the thread, appearing in the milling-thread } \\
\text { operation. } \\
\text { The cause of the occurrence is to block the } \\
\text { machine-tool and move it only one axis, not two } \\
\text { axes as it did before. }\end{array}$ \\
\hline 4 & $\begin{array}{l}04 / \\
21.01 .17\end{array}$ & $\begin{array}{l}\text { Kaplan pallet } \\
\text { chuck } \\
\text { (customer's semi- } \\
\text { finished product } \\
\text { processing)) }\end{array}$ & 16 & $\mathrm{C} 5$ & $\begin{array}{l}\text { The roughness of } 1.6, \text { on the } \varnothing 1470 \text { e } 6 \text { diameter, } \\
\text { according to the execution drawing, was made of } \\
2.13 \div 2.71 \text { and the diameter between } \varnothing 1469.72 \\
\div 1469.74 \mathrm{~mm} \text {. } \\
\text { The cause of the occurrence is the lack of a } \\
\text { grinding operation. }\end{array}$ \\
\hline 5 & $\begin{array}{l}05 / \\
21.01 .17\end{array}$ & $\begin{array}{l}\text { Inferior }+ \\
\text { superior piston's } \\
\text { labyrinth-holder } \\
\text { (Repair/ } \\
\text { Reconditioning) } \\
\end{array}$ & 5 & G5 & $\begin{array}{l}\text { In the finishing turning operation pore appeared } \\
\text { in the composite material cast on this surface, } \\
\text { and the } \varnothing 445 \mathrm{~mm} \text { was made of } \varnothing 451.6 \mathrm{~mm} \text {. } \\
\text { The cause of the occurrence is the lack of } \\
\text { technology verification, human error. }\end{array}$ \\
\hline 6 & $\begin{array}{l}06 / \\
23.01 .17\end{array}$ & $\begin{array}{l}\text { Kaplan pallet } \\
\text { chuck - semi- } \\
\text { finished product } \\
\text { (customer's semi- } \\
\text { finished product } \\
\text { processing) }\end{array}$ & 21 & $\mathrm{C} 7$ & $\begin{array}{l}\text { At customer's request there was a gap from the } \\
\text { workpiece's axis for } \varnothing 117 \mathrm{~mm} \text { holes, which } \\
\text { generated } 7 \text { tool inlets on a } 170^{\circ} \text { arc with a width } \\
\text { of up to } 12.82 \mathrm{~mm} \text { and a depth of } 0.5 \mathrm{~mm} \text {. } \\
\text { The cause of the occurrence is the cancellation of } \\
\text { the requirement by the customer after starting the } \\
\text { respective processing operation. }\end{array}$ \\
\hline 7 & $\begin{array}{l}07 / \\
23.01 .17\end{array}$ & $\begin{array}{l}\text { Inferior + } \\
\text { superior pallet- } \\
\text { holder (Repair/ } \\
\text { Reconditioning) }\end{array}$ & 16 & $\mathrm{C} 1$ & $\begin{array}{l}\text { Dimension of } 10-0.04 \text { from the } 6 \text { channels has } \\
\text { been performed at } 9.83 \div 9.84 \mathrm{~mm}[6] \text {. The cause } \\
\text { is given by the operator who measured with a } \\
\text { micrometer without considering that the rod } \\
\text { surface measuring instrument is flat and } \\
\text { machined surface is cylindrical. }\end{array}$ \\
\hline 8 & $\begin{array}{l}08 / \\
24.01 .17\end{array}$ & $\begin{array}{l}\text { Front bearing } \\
\text { box (customer's } \\
\text { semi-finished } \\
\text { product } \\
\text { processing) }\end{array}$ & 16 & C9 & $\begin{array}{l}\text { In two of the threaded holes M30 the caliber } \\
\text { enters with "no go" side, along the whole thread } \\
\text { length (gap). } \\
\text { The cause of the occurrence is due to the use of } \\
\text { an inadequate tool, human error. }\end{array}$ \\
\hline 9 & $\begin{array}{l}09 / \\
27.01 .17\end{array}$ & $\begin{array}{l}\text { Pallet chuck } \\
\text { (customer's semi- } \\
\text { finished product } \\
\text { processing) }\end{array}$ & 16 & $\mathrm{C} 1$ & $\begin{array}{l}\text { The "G3" hole in the execution drawing, } \\
\text { (drawing dimension } \varnothing 210+0.115 \text { ) was made at } \\
\text { the } \varnothing 210.56 \text {. } \\
\text { The cause is given by difficult access to the } \\
\text { surface and use of inappropriate tools. }\end{array}$ \\
\hline 10 & $\begin{array}{l}10 / \\
27.01 .17\end{array}$ & $\begin{array}{c}\text { Lower valve } \\
\text { bush (execution) }\end{array}$ & 19 & $\mathrm{~F} 4$ & $\begin{array}{l}\text { The parts show defects (microcracks) highlighted } \\
\text { by the LP control, according to the LP no. } \\
67 / 2017 \text {. } \\
\text { The cause of the occurrence is the choice of an } \\
\text { inappropriate blank from the stock. }\end{array}$ \\
\hline
\end{tabular}


Solving these nonconformities was done as follows:

- for RN 01 / 14.01.17 - Kaplan pallet chuck semi-finished product: the part is accepted as such, the customer obtaining the approval of its final customer, based on the DDR Exemption Application No. 2 / 30.01.17;

- for RN 02 / 15.01.17 - Monobloc rotor: verification and marking of add-ons for confusion elimination $[7,8]$;

- for RN 03 / 16.01.17 - Bowl: Edge adjustment and acceptance as such, based on the DDR Exemption Application No. 1 / 22.01.17. The piece has been inspected with LP [9] on the adjusted areas and adjacent surfaces;

- for RN 04 / 21.01.17 - Kaplan pallet chuck semi finished: the revision of the technology. Immediate polishing of the surface, without affecting the diameter, a minimum diameter of $\varnothing 1469.70 \mathrm{~mm}$ is accepted, based on DDR Exemption Application No. 3 / 30.01.17;

- for RN 05/ 21.01.17 - Inferior + superior piston labyrinth-holder: Composite material return and repeat operation [10];

- for RN 06/ 23.01.17 - Kaplan pallet chuck semi-finished product: the part is accepted as such, based on DDR Nr. 4/ 30.01.17;

- for RN 07/ 23.01.17 - Inferior + superior pallet-holder: designer's solution: realization of the labyrinth sealing area, of the rotor counterpart, consequently with the erroneous quotation on the pallet;

- for RN 08/ 24.01.17 - Front bearing box: designer's solution: Thread increase at M35;

- for RN 09/ 27.01.17 - Pallet chuck: acceptance as such diameter $\varnothing 210.56$ conditioning counterpart execution to the hole dimension, based on the request for derogation DDR No. 5 / 02.01.17;

- for RN 10/ 27.01.17- Lower valve bush: New part execution.

\section{Conclusions}

Following the non-compliance reports that occurred during the month presented above, the following improvement proposals were done:

- additional training of staff involved in Kaplan blades processing, to improve the manufacturing process of these types of parts;

- improving the working environment by auxiliary measures, such as additional lighting of workplaces;

- simulation of numerical control programs, before starting each phase of an operation;

- additional measurements during the operations;

- acquisition of non-destructive tested semifinished products, in prior;
- increasing the annual number of audits performed at suppliers;

- all reports submitted were closed in less than 30 days.

The Annual Analysis highlights the number of NR issued by codes of cause and defect, specifies the number of NR remaining open at the date of drawing, that year and separately in previous years, to ensure a pertinent analysis of the trend of nonconformities and their causes. Coding nonconformities gives the possibility to be classified at any time, with the following benefits: intervening on the processes in a timely manner, by further training of staff; taking additional precautions: Pokayoke; obtaining data for performing FMEA analyses; fault tree; lowering the cost of non-quality.

\section{References}

[1]. Dumitru-Titi Cicic, Liliana Niţu, Gheorghe Solomon, Oana Bratosin, Lucian Daniel Nițu, Quality Management. Aplications, Printech Publishing Company, Bucharest, 2014.

[2]. ***, SR EN ISO 9000: 2015, Quality management systems. Fundamental and vocabulary principles.

[3]. ***, SR EN ISO 9001: 2015, Quality management systems. Requirements.

[4]. ***, SR ISO 10005: 2007, Quality Management Systems. Guidelines for Quality Plans.

[5]. Gabriel Marius Dumitru, Constantin Radu, Bogdan Dumitru, Reconditioning and repairing products, Printech publisher, Bucharest, 2010.

[6]. Dragu D., Bădescu Gh., Sturzu A., Militaru C., Popescu I., Tolerances and technical measurements, Bucharest, 1980.

[7]. Amza Gh., Radu C., Apostolescu Z., Amza C. Gh., Dumitrache-Rujinski A., Gârleanu G., Gârleanu D., Operating precesses, vol. 1, Bucharest, 2001.

[8]. Amza Gh., Radu C., Apostolescu Z., Amza C. Gh., Dumitrache-Rujinski A., Gârleanu G., Gârleanu D., Operating precesses, vol. 2, Bucharest, 2001.

[9]. Voicu M., Mihai A., Dumitrache- Rujinski A., Mateiaşi G., Dumitraşcu C., Popovici V., Funar S., Păuşan D., Nondistructive examinations, Printech Publishing Company, Bucharest, 2009.

[10]. Amza Gh. et al., Materials technology, vol. 1, Bucuresti, 1997.

[11]. Ivanov Nikolay, A Study on Optimization of Nonconformities Management Cost in the Quality Management System (QMS) of Small-sized Enterprise of the Construction Industry, Procedia Engineering, vol. 153, p. 228-231, 2016.

[13]. Uma Maheswaria J., Paul C. Charlesrajb V., Sandeep Kumara G., Sreenivas Padalaa S. P., A Study on Assessment of Non-conformances using Multiple Domain Matrix: A Case Study from Metro Projects, Procedia Engineering, vol. 145, p. 622-629, 2016.

[14]. Kumar G. S., Assessment of Non-Conformance report (NCR) based delays using Multiple Domain Matrix (MDM): Case study of Metro Project, M. Tech Thesis. Indian Institute of Technology, Delhi, 2015.

[15]. Burati J. L., Farrington J. J., Ledbetter W. B., Causes of quality deviations in design and construction, J. Constr. Eng. Mgt. 118 (1), p. 34-49, 1992.

[16]. Karkoszka T., Audits as a Manner of Conformity Assessment and Improvement Guidelines in the Organisation, Key Engineering Materials, Advances in Manufacturing Systems, vol. 502, p. 31-36. [17]. Marius Bulgaru, Lucian Fulea, Marian Borzan, Vlad Bocăneț, Silviu Ilas, Using Six Sigma Methodology to Reduce 


\section{THE ANNALS OF "DUNAREA DE JOS” UNIVERSITY OF GALATI \\ FASCICLE IX. METALLURGY AND MATERIALS SCIENCE \\ No. 3 - 2018, ISSN 2668-4748; e-ISSN 2668-4756 \\ Article DOI: https://doi.org/10.35219/mms.2018.3.06}

Nonconformities, Applied Mechanics and Materials, vol. 809-810, Innovative Manufacturing Engineering, p. 1287-1292, 2015.

[18]. Bernardo M., Casadesus M., Karapetrovic S., Heras I. How integrated are environmental, quality and other standardized management systems? An empirical study, Journal of Cleaner Production, 17 (8), p. 742-750, 2009.

[19]. Bergman B., Klefsjö B., Quality from Customer Needs to Customer Satisfaction, Second Edition, Studentlitteratur, Lund, 2003.
[20]. Militaru E. M., Moroșanu A. D., Hudea L., Dumitru M. G., Research of NDT examination of the turbine parts using magnetic particles, Conference Proceedings of the Academy of Romanian Scientists, Productica Scientific Session, vol. 7, no. 1, ISSN 2067-2160, Editura Academiei Oamenilor de Ştiinţă din România, Bucureşti, 2015.

[21]. Militaru E. M., Moroşanu A. D., Goran M., Dumitru M. G., Research of NDT examination of the turbine components using liquid penetrant inspection, TEHNOMUS Journal New. 